\title{
Research on Disney's Possible Expansion Strategy in Asian Market
}

\author{
Ziying Hua ${ }^{1, *}, \dagger$, Hao Song ${ }^{2, *, \dagger}$, Kunzhi Zou ${ }^{3, *, \dagger}$ \\ ${ }^{1}$ Capilano University, North Vancouver, Canada \\ ${ }^{2}$ Qingdao No.9 Senior High School, Qingdao, Shandong, China \\ ${ }^{3}$ Xiamen No.1 High School, Xiamen, Fujian, China \\ *Corresponding author. Email: guanghua.ren@gecacdemy.cn \\ These authors contributed equally.
}

\begin{abstract}
Disney's financial statement shows that from 2011 to 2020, Walt Disney mainly gains its revenue through Canadian and American market, but fail to effectively gain profit in Asia, especially in China--Shanghai Disneyland fails to provide respectable income for Disney. This phenomenon, known as inorganic growth, needs to be improved to ensure Disney's successful development in the future. So, in this paper, the fundamental problem for Walt Disney's globalization is whether Walt Disney will have a broad market prophet in China in the future. The proposed method to solve the problem is comparing Disney and its competitors, the analysis of the overall external situation in China, and the choice of locations in China. Each part is divided into three sections to provide a detailed and comprehensive analysis supported by tables and graphs. The data are mainly obtained from authoritative journals and international performance studies. The results indicate that Disney is supposed to make several improvements to ensure that it can open a brand-new Chinese market and keep leading the market as it used to be. The analysis is significant because it relates to the future globalization of Walt Disney in China that whether it can reverse the current inorganic growth and allows the Asia area to account for a larger percentage of total revenue. Financial and real estate's elements are also taken into consideration.
\end{abstract}

Keywords: Disney; Market; Expansion.

\section{INTRODUCTION}

Disney's story has been sustained for nearly one hundred years, and it will be continuing to exist in the business world. Disney did indeed own a big share in entertainment, movie, and many industries in the market. However, the competitors are increasing and stronger as time passing. There is no denying that Disney is losing its market share from good to bad. Disney should not focus on the short-term interest, which relies on the market it used to own in North America, and it needs to put the view on the long run interest such as expanding its market worldwide. This academic paper gave a specific market expansion strategy on how to transfer some of the markets into Asia countries and did deep research on most of the possible positive and negative results that might occur after the expansion. Walter Disney's company does have a good reputation worldwide and a huge amount of cash flow to start the expansion program, which makes the strategy easier; however, the weakness is that Disney may make some irreversible mistakes because of the lack of cultural understanding. When entering a new area, Disney will be facing new opportunities and challenges such as cultural differences, new competitors, and different business methods. From another perspective, it means that Disney may open a brand-new market and keep leading the market as it used to be. Therefore, it is necessary to lay a solid foundation for Disney's basic market start point to establish the future reputation in the Chinese Market. Disney could start with building the resorts in different Cities in China to attract the population and the social attention to establish a good reputation in a new culture.

Weng et al. claim that when implementing the market expansion strategy in Shanghai, the report shows that it also brings the demand spillover effect to Shanghai and cities around there. When the resort has been established, the demand of the hotel industry is showing an increasing trend. According to the report, the 
researcher separates the opening process into four levels: T1 (pre-opening), T2(Post-opening), T3(Post-opening), and T4(Post-opening). The result has shown that these cities are increasing some percentage after the Post opening [1]. Boog and Milliot's research shows that as the movie and entertainment industry grows, Disney has a plan to expand their teenager market. Tonya Agurto claims that Disney is planning to focus on the "acquiring" and "develop global content" area, and this will help Disney control the social reputation through a different platform. When mentioning the process of expanding the teenager market worldwide, the movie sector will be an indispensable part. Disney is planning to create more movies based on imaginary and real stories [2]. Prevot and Hsieh illustrate that to expand the Disney market into French, investigating the local culture, market environment, and customers' preferences is Walter Disney company's primary choice. Disney does have a wrong recognition of European's average income and causing they are losing customers because they set a high amount of ticket price [3]. To open the movie market in China, Disney needs to make the right move in the movie industry and respect the government policy and culture. $\mathrm{Yu}$ states that Disney made a mistake in the movie "Kundun" and directly causing the loss of market in China. However, Disney decides to open the movie market with an old traditional story, "Mulan," and it succeeds. The success of "Mulan" has attracted Chinese investors, and it helps Disney cooperate with the Shanghai Shendi group to start the resort plan [4].

Yu examines the behavior of Walt Disney Company in entering the Chinese market from the perspective of political economy. Analyzing the events related to "Kundun" and "Mulan", combines the event with the period and makes a horizontal comparison and summary. Finally, it is concluded that China's state capitalism has replaced the planned economy. Moreover, in 2012, China has replaced Japan as the largest box office market after the United States, which means that the contradiction between China and Disney and other film companies still exists [5]. Bohas takes Disney Company as an example to illustrate how to promote the global development of the company. Bohas conducted in-depth interviews and questionnaires in different regions of France to obtain the views and suggestions of residents on the transnational development of Disney. Finally, it is concluded that when a company follows the local cultural background and strengthens the degree of cultural embedding, it can be more easily accepted by local consumers [6]. Carson found the value of music in the "Disney experience" by tracing the role of music in the history of different companies worldwide. Carson listed the use of music by people in different regions such as the United States, Mexico, and Germany and substituted Disney's music into the examples. Finally, it was summarized that Disney wanted to help people deepen their memory in Disney through theme music so that tourists can recall their past travel and imagine their future travel by listening to theme music after leaving [7]. Michaud and Auster studied Disney's depiction of gender and race. By analyzing the characters on the official website of five theme parks for marketing, the depiction of animal images, and the protagonists in films, comics, and other art works. Finally, it is concluded that the character's race and gender are unbalanced. Still, with the progress of the times, this phenomenon is shrinking, and most consumers maintain a positive attitude towards this phenomenon [8].

Currently, Shanghai Disneyland is working on the right track. Wu provides a deep analysis of the operation of Shanghai Disney's marketing strategy from 3 perspectives: the reliance on rich marketing experience of the integration of globalization and localization, the implementation of scene-based marketing strategies from IP building, and immersive scene and online recording drive. Wu Dan finally concludes that Shanghai Disney successfully explores the culture deeply, creates a theme park with market uniqueness, and forms a collective, coordinated operation system [9]. Souvenirs play a crucial role in Disney's annual revenue. Wei explores souvenir values under the influence of contemporary Chinese culture. Wei Wei identifies three overarching souvenir values germane to modern Chinese culture, encompassed by sign value, meaningfulness, and hedonistic value and provides a list of seven other values that are found to uniquely exist depending on the specific recipient of souvenirs. Based on data analysis of 32 inperson interviews, Wei Wei found that sign value, meaningfulness, and hedonistic is the primary and tangent values associated with souvenir purchase in the context of Disney theme parks. Besides, Chinese consumers pay more attention to family orientation and tend to buy souvenirs with positive values when the recipients are children [10]. As the process of globalization has intensified, the economic boundaries between countries have become increasingly blurred. At the same time, cultural conflicts caused by cultural differences between countries, regions, and ethnic groups have become the core problem of various business managers. As a result, cross-cultural management emerged as an independent discipline. Huang uses the business case analysis method to compare two overseas expansions of Disney--the success of Tokyo Disneyland and the failure of Disneyland Paris--to emphasize the necessity of cross-culture management. He concludes the crucial points of crossculture management: respect, adapts, blends, innovate, and localize [11]. Using a vacation town of Shanghai Disney Resort as a case, Weng et al. analyzed the demand spillover effect by measuring the market power of the hotels. They revealed that the scope of demand spillover in space was mainly concentrated in the Shanghai city proper. Still, they showed multi-point spread from Shanghai Disney Resort, Hongqiao 
transportation hub, and central business district. Temporally, the hotel market power in different locations did not change in synchrony but exhibited the characteristics of ebb and flow. This type of spatialtemporal change suggested that it was not only the geographical distance that affected the demand spillover effect but also the function of the location itself. This study further demonstrated a simple and feasible method for using market power to analyze the spatial-temporal process of demand spillover effect [12].

To explore the impact and significance of Disney's establishment of a new theme park in China, the differences between Disney and similar theme parks such as fiantaweld in adapting to social culture and souvenir design are analyzed and compared in different aspects. And the impact of Disney on the surrounding environment in terms of economy, culture, and education. In addition to Disney's historical process of globalization and localization, the location of Disney's new theme park in China is finally speculated.

\section{COMPARISON}

To analyze Walt Disney Company's advantages and advantages and find out whether it is wise for Disney to expand in Asia, I respectively compare Disney to Universal Studios, Fantawild in wuhu, and Changlong. It is because that Universal Studio has been one of the greatest competitors worldwide, while Fantawild and Changlong are two of the biggest competitors in the Chinese market.

\subsection{Comparison of Walt Disney and the Universal Studio for their marketing strategies.}

For Walt Disney:

Table 1. Advantages and disadvantages of different environment models

\begin{tabular}{|l|l|l|}
\hline & Disney & Universal Studio \\
\hline $\begin{array}{l}\text { Entertaining } \\
\text { experience }\end{array}$ & $\begin{array}{l}\text { Mild, more suitable for } \\
\text { kids } \\
\text { Own "Disney culture." }\end{array}$ & $\begin{array}{l}\text { Magical and } \\
\text { stimulating, more } \\
\text { suitable for teens } \\
\text { and adults. }\end{array}$ \\
\hline Pricing strategy & $\begin{array}{l}\text { Flexible. Like } \\
\text { providing differential } \\
\text { and regional pricing. }\end{array}$ & $\begin{array}{l}\text { Relatively } \\
\text { inflexible. } \\
\text { Normally there is } \\
\text { only the same } \\
\text { pass all year } \\
\text { round. }\end{array}$ \\
\hline $\begin{array}{l}\text { Promotion } \\
\text { tools }\end{array}$ & $\begin{array}{l}\text { cover nearly all } \\
\text { marketing channels }\end{array}$ & $\begin{array}{l}\text { Variety } \\
\text { promotion tools }\end{array}$ \\
\hline Plus & $\begin{array}{l}\text { Diversified products. } \\
\text { Using franchise to } \\
\text { expend (transferring } \\
\text { intangible assets to its } \\
\text { trademark brands) [13] }\end{array}$ & $\begin{array}{l}\text { The separate } \\
\text { theme for each } \\
\text { park. [13] Its } \\
\text { souvenirs are of } \\
\text { higher cost-effect. }\end{array}$ \\
\hline
\end{tabular}

\section{Comparison and Analysis:}

Disney is more suitable for children with cartoon characters and mild stimulate, whereas Universal Studio is more appealing to teenagers. Like Sea Witch, a trill project in Universal studio that I personally favor may be a bit scary for children. Disney's pricing strategy, which regularly adjusts as changes occur, is more flexible than Universal Studio's Day, season, and annual passes. Disney relatively covers a wider area due to more parks currently and focuses more on integration and brand alliance.

\section{Disney's Improving Methods}

Disney is supposed to (1) build theme parks that meet certain requirements to make them more fascinating (2) combine high technology with theme parks' infrastructures to create an atmosphere that is suitable for the whole family and strives to meet all types of needs, (3) maintain high creativity to increase the competitive and maintain customers' loyalty. (4) expend its "Disney culture", apply cultural concepts to recreational activities, and educate children through games. (5) Keep providing flexible tickets.

\subsection{Maintaining the Integrity of the Specifications}

Under price disadvantages, what does Disney have to attract Chinese visitors? Based on the research of Zhao \& Lu. [14], this paper mainly focuses on 5 perspectives to consider tourists' motivation of Disney and Fantawild: (1) Seeking knowledge (2) Finding novelty (3) Social (4) Kinship/Relationship (5) Attraction of the parks' souvenirs

Table 2. Comparison for shanghai disneyland and fiantawild in wuhu for why visitors come

\begin{tabular}{|l|l|l|}
\hline & $\begin{array}{l}\text { Shanghai } \\
\text { Disneyland }\end{array}$ & $\begin{array}{l}\text { Fantawild in } \\
\text { Wuhu }\end{array}$ \\
\hline Seeking knowledge & $\begin{array}{l}\text { Offers visitors a } \\
\text { unique experience } \\
\text { through innovative } \\
\text { entertainment } \\
\text { programs and } \\
\text { performances. }\end{array}$ & $\begin{array}{l}\text { Fail } \\
\text { effectively offer } \\
\text { appealing } \\
\text { knowledge to } \\
\text { visitors. }\end{array}$ \\
\hline Finding novelty & $\begin{array}{l}\text { More appalling to } \\
\text { customers due to } \\
\text { larger investment } \\
\text { strengthens, appears } \\
\text { capital, and land } \\
\text { area. }\end{array}$ & $\begin{array}{l}\text { It } \\
\text { insignificant compared } \\
\text { with Shanghai } \\
\text { Disney's } \\
\text { investment and } \\
\text { brand reputation. }\end{array}$ \\
& $\begin{array}{l}\text { More attractive to } \\
\text { visitors due to } \\
\text { mental preference } \\
\text { and materially } \\
\text { ability. }\end{array}$ & $\begin{array}{l}\text { It seems that } \\
\text { Fantawild is not } \\
\text { an excellent } \\
\text { place for } \\
\text { socializing. }\end{array}$ \\
\hline Social & \multicolumn{2}{|c|}{} \\
\hline
\end{tabular}




\begin{tabular}{|l|l|l|}
\hline Kinship/Relationship & $\begin{array}{l}\text { "visiting relatives } \\
\text { and friends" }\end{array}$ & $\begin{array}{l}\text { "satisfy } \\
\text { children's } \\
\text { interest." }\end{array}$ \\
\hline $\begin{array}{l}\text { The attraction of the } \\
\text { parks' souvenirs }\end{array}$ & $\begin{array}{l}\text { Attractive relied } \\
\text { on its "Disney } \\
\text { culture." }\end{array}$ & $\begin{array}{l}\text { Very few } \\
\text { customers pay } \\
\text { for the souvenirs. }\end{array}$ \\
\hline
\end{tabular}

(The following provides a deep analysis for each perspective.)

Compared with Fantawild, the motivation of knowledge-seeking of Shanghai Disney tourists has two more observation variables: "enriching their own experience" and "increasing the function of knowledge education". This is inseparable from the diversified and innovative tourism products of Shanghai Disney, which offers visitors a unique experience through innovative entertainment programs and performances. The inside of Shanghai Disneyland, including its architectural design, entertainment programs, and performances, is also a way to gain knowledge. Shanghai Disney has launched a special "Disney Youth Program" to create a unique and magical experience for children, making a fun trip to Shanghai Disney and a learning trip.

The path coefficient between the total motivation of Shanghai Disney tourists and the motivation of "exploring new and different" is larger than that of Fantawild [14]: first of all, Shanghai Disney is larger than Wuhu Fantawild in terms of investment strength, land area, and other aspects, and up to $80 \%$ of the amusement facilities in Shanghai Disney are newly designed, which enhances the motivation of tourists to spend time with. Moreover, with the support of a strong brand, a large amount of capital has been invested in technological innovation, doing advanced high-tech projects that focus on attracting tourists. As a wellknown theme park in China, Fantawild has invested a lot in technology and project innovation. Still, it appears insignificant when compared with Shanghai Disney's investment and brand reputation.

Social interaction" Motivation Difference The path coefficient between the total motivation and "social interaction" motivation of Shanghai Disney tourists is larger than that of Fantawild [1], indicating that the correlation between the total motivation of Shanghai Disney tourists and "social interaction" motivation is significantly greater than that of Fantawild. This is mainly because of the difference in the brand awareness of Shanghai Disneyland and Fantawild--the international brand is more attractive than the localization brand. In accordance with powerful groups, Shanghai Disneyland had a strong capital and broad market as well as excellent talents. Thus construction plan is widely and greatly followed, established the strong brand influence [15]. Therefore, compared with Fantawild, Shanghai Disneyland as a tourist destination, from tourists' perspective, can reveal their identity and position [16]. It is fresher and more meaningful to share the travel experience of Disneyland with friends.

In motivation of Kinship, Shanghai Disney tourists and the motivation of "family love" is significantly larger than that of Fantawild, and the contents of the motivation of "family love" are also different.[1] The motivation of "visiting relatives and friends" appears in Shanghai Disneyland, while wuhu Fantawild does not, which is closely related to the level of social and economic development of Shanghai and Wuhu.: Shanghai is an international city located in the core area of the Yangtze River Delta, with convenient transportation, a variety of services, entertainment facilities that can meet the various needs of tourists. The motivation to "satisfy children's interest" was not as evident among Shanghai visitors as it was in Wuhu Fantawild. This can be attributed to three reasons: First, Shanghai Disneyland season tickets price is higher, more than 500 yuan, while the tickets of Fantawild are lower than 259 yuan. When foreign brands' prices relative to the local brands are much higher, consumers may intend to switch to alternatives in local brands [17], like Fantawild.

Buying Disney gifts affects the tourism motivation of Shanghai Disney tourists to a certain extent. In contrast, most wuhu Fantawild tourists do not have the motivation to buy special souvenirs before traveling. This is closely related to the promotion and marketingsupported by the brand and the development of the industrial chain. Disney promotes its brand through a variety of media and scenes, accumulating visibility. Also, it allows customers to buy their products anywhere worldwide [18]. However, only very few amounts of customers pay for Fantawild's products, which can be attributed to the disconnection between online and offline.

Shanghai Disneyland visitors' total tourism motivation of "Seeking knowledge" a "Finding novelty", "kinship" and "social" is bigger than the correlation of wuhu Fantawild: "own rich experiences," "increases the knowledge education". Also, buying Disney's souvenir/gift somewhat affects the Shanghai Disneyland visitors' travel motivation. This indicates that international brands are far more attractive and influential to tourists than local brands, and thus Disney is supposed to extend and develop in China market.

\subsection{Experience Perception of Shanghai Disney's Hotel and Guangzhou Changlong's Hotel}

Disney, a theme park giant, earns more than 60 percent of its revenue from hotels, restaurants, and souvenirs. Therefore, the research on the derivative industry of theme parks -- theme hotels is related to the 
development direction of future theme parks. However, in the Chinese market, one of the biggest competitors is Guangzhou Changlong Hotel. Based on the research of Litvin [19] and Leung [20], I decide to analyse Shanghai Disney's and Guangzhou Changlong's hotel through word frequency analysis instead of semantic network analysis, as well as effective tendency and satisfaction analysis.

Table 3. The high-frequency words (from dianping) comparison of shanghai disneyland and guangzhou changlong hotel[21]

\begin{tabular}{|l|l|l|}
\hline & $\begin{array}{l}\text { Shanghai Disney } \\
\text { Hotel }\end{array}$ & $\begin{array}{l}\text { Guangzhou } \\
\text { Changlong Hotel }\end{array}$ \\
\hline Hotel Service & $\begin{array}{l}\text { Service, luggage, } \\
\text { free, waiter }\end{array}$ & Service, free, waiter \\
\hline Hotel facilities & $\begin{array}{l}\text { Room, facilities, } \\
\text { breakfast, lobby, } \\
\text { bed, front desk, } \\
\text { restaurant, TV, } \\
\text { elevator, } \\
\text { swimming pool, } \\
\text { decoration. }\end{array}$ & $\begin{array}{l}\text { loom, restaurant, } \\
\text { facilities, breakfast, } \\
\text { slippers, front desk, } \\
\text { wash, bath, taste, } \\
\text { buffet, fruit, toilet, } \\
\text { complete, toothbrush }\end{array}$ \\
\hline $\begin{array}{l}\text { Hotel } \\
\text { Environment }\end{array}$ & $\begin{array}{l}\text { Shanghai, location, } \\
\text { Hong Kong, } \\
\text { transportation, } \\
\text { toys, environment, } \\
\text { garden, fireworks, }\end{array}$ & $\begin{array}{l}\text { white tiger, animal, } \\
\text { location, flamingo, } \\
\text { environment, } \\
\text { Guangzhou, wild, } \\
\text { Zhuhai, health, } \\
\text { transportation, clean, } \\
\text { comfortable, cat, } \\
\text { scenic spot }\end{array}$ \\
\hline $\begin{array}{l}\text { Accommodation } \\
\text { companions }\end{array}$ & $\begin{array}{l}\text { children, parents, } \\
\text { family, friends }\end{array}$ & $\begin{array}{l}\text { children, parents, } \\
\text { family, friends }\end{array}$ \\
\hline Experience & $\begin{array}{l}\text { convenient, cost } \\
\text { experience, cost } \\
\text { performance, group } \\
\text { photo, reservation, } \\
\text { photo, satisfaction, } \\
\text { experience, cost- } \\
\text { effective, } \\
\text { characteristics, } \\
\text { happy, satisfied, } \\
\text { intimate, }\end{array}$ \\
\hline
\end{tabular}

No serious difference. But generally, there is a tendency that considering Disney's service is better. Shanghai Disney Hotel pays more attention to the overall Disney dream style, focusing more on details, whereas Guangzhou Changlong hotel pays more attention to the intimate daily necessities. Easily, Shanghai Disneyland mainly focuses on the Disney dream and cartoon image, creating a fairy tale castle theme hotel, while Guangzhou Changlong hotel mainly highlights wildlife theme so that customers can view and admire white tigers and flamingos in the hotel closely. Mostly same. Disney is supposed to figure out better ways to attract them, like providing family and couple packages. Though most people hold a positive attitude toward Disney's and Changlong's hotels, a great number of people complain that Guangzhou Changlong's Hotel is really wet. In Shanghai Disney Hotel, "taking photos" accounts for a high proportion of the high-frequency words, indicating that taking photos with Disney cartoon characters in the hotel is an unforgettable experience for customers. It shortens the distance between the hotel and customers and enhances the experience of the hotel.

Thorough analysis, it is not hard to see that Guangzhou Changlong Hotel is highly competitive. For Shanghai Disney, there are still some actions that can be done to improve the attraction. First, promise good service. Besides, keep creating the fairy tale theme hotel, and provide some bundled packages for parents and couples at the same time. Third, it provides clean rooms. Changlong Hotel has suffered great negative comments because of the wet condition.

\section{INFLUENCE ON OTHER AREAS}

\section{1. economy}

When establishing the Disney culture and the resorts in Shanghai will impact the tourism performance in surrounding cities. According to Statista [22], Shanghai is a city that has a huge number of foreign visitors in the tourism industry. The number of visitors has increased from 224.32 million in 2010 to 361.41 million in 2019 [23]. This data refers to the huge potential consumptive power that could be gained from the tourists' amount in Shanghai. Moreover, when implementing the Disney marketing plan in Shanghai, it will also increase the huge number of tourists in the surrounding cities. The increase in tourists will stimulate the hotel and service industry in the surrounding cities such as Suzhou and Nantong. Suzhou has a growing trend of GDP from 1.73 trillion in 2017 to 1.92 million in 2019 [24]. The economy will show an increasing trend after the increase of tourists. In addition, Disney's doll culture will affect the manufacturing industry and raising productivity.

\subsection{Culture}

As the Economy exhibition city in China, Shanghai is taking the leading position. The expansion of the Disney market in Shanghai will positively affect other cities. Disney's culture has a strong influence worldwide. To open the movie industry in China, Disney needs to make the right moves about it because it had a failure in the movie "Kundun," which brings Disney a lot of negative impacts. Fortunately, The Movie "Mulan" is very successful in the Chinese Market and worldwide [25]. The Chinese audience starts to accept Disney's movie culture and is willing to see movies from a different culture. It will impact the surrounding cities' local culture and affected the locals. The foreigners who didn't visit Shanghai will get a chance to know things about Shanghai and the surrounding cities by watching the movies. Since Disney does have a well-known reputation, it is easy for 
foreigners to know the surrounding cities by spreading the Disney culture.

\subsection{Education \& policy}

The surrounding cities will change the policy and encourage more investments in different areas when they see the success of Disney theme parks. This will effectively enhance the GDP per city and raise the value of RMB. For example, the West Virginia government wants to invest in the Disney theme park to motivate tourism. Even though the purpose of the West Virginia government is to decrease the tax, but it still shows the huge benefits the investment in Disney could bring to a city [26].

By entering Shanghai, Disney's marketing strategy will be mainly focusing on kids and teenagers. When focusing on the teenager market, Disney provides a lot of history stories in animation to help kids see the world [27].

\section{DISNEY'S GLOBALIZATION IN CHINA}

\subsection{Disney's globalization process}

Globalization will increase the potential market tension for Disney's international sales and reduce its cost and facilitate its implementation of better works of art.

Table 4. HISTORY OF GLOBALIZATION OF DISNEY THEME PARK

\begin{tabular}{|c|l|}
\hline Year & Position \\
\hline 1955 & Disneyland Resort California \\
\hline 1971 & Walt Disney World Resort Orlando \\
\hline 1983 & Tokyo Disney Resort \\
\hline 1992 & Disneyland Resort Paris \\
\hline 2005 & Hong Kong Disneyland Resort \\
\hline 2016 & Shanghai Disney Resort \\
\hline
\end{tabular}

From the historical development of Disney, the "Disney Brothers Studio" was established in 1922. Until the release of the crazy plane, Disney opened the door of globalization. After Walt's death, Disney animation began to transform and seek a new niche market, so "save the little hero" went online, changed the traditional theme song with full popularity, and began to attract consumers worldwide. To explore more markets, they continued to develop film and theme park businesses while establishing theme parks worldwide. In addition, it began to build its own huge media network, successively incorporated ESPN, ABC, and other television stations, and expanded its business to consumer goods and interactive media. Later, Disney acquired world-famous film companies and characters, such as paramount, Columbia, Warner Brothers, universal film, fox, etc. This has laid the foundation for opening the global market. At present, Disney is in the stage of seeking international alliances, such as cobranding with major international brands, such as UNIQLO, which is in the transition period of immature and consolidated position in globalization. The global strategy will continue to focus on animation and expand its business model to other businesses, continuously expand and acquire copyright around the world, and continuously localize at the same time, expand consumer groups and implement the strategy of globalization and full copyright.

\subsection{Disney's localization strategy}

From the release of Cinderella in 2015 to Liu Yifei in Mulan in 2019, Disney has never intended to give up the broad Chinese market but is more committed to developing the local Chinese market. However, when Hollywood adapts films, it often ignores the differences between Eastern and Western cultures and will misinterpret and symbolize the cultures of other countries to a certain extent. For example, in the previous Mulan Reality Show Trailer, the earth building in Fujian caused a huge response on social networks. However, it is undeniable that Disney is determined to promote localization in the Chinese market. According to the analysis report on market foresight and strategic investment planning of the film industry released by the foresight Industry Research Institute, the total box office of Chinese films increased from 4.341 billion yuan to 60 billion yuan in the decade 2008-2018, becoming the second-largest film market in the world after the United States. The main slogan of the Disney theme park in Shanghai is original Disney, unique Chinese style. In Paris, France, Disneyland is allowed to sell red wine; In Tokyo, Japan, Disneyland has an exciting Disney Sea; In Hong Kong, China, Mickey Mouse in Disneyland wears Tang clothes "Every Disneyland in the world has a different design. We will also tailor it for Shanghai". Disney staff revealed that while retaining Disney Classics, Shanghai Disneyland under construction will make some localization changes in individual details according to Shanghai characteristics. For example, the 11-acre Magic Garden in the center of Shanghai Disneyland imitates Chinese gardens, and the trees on both sides of the main road of the garden are unique to Shanghai. For another example, there is a distinctive "Twelve friends garden", in which 12 large murals are placed to show the images of China's twelve zodiac animals with well-known Disney story characters. There are colorful cherry blossoms in the garden. Visitors can enjoy the unique beauty of Disneyland, listen to the melodious melody, and participate in various wonderful activities. 

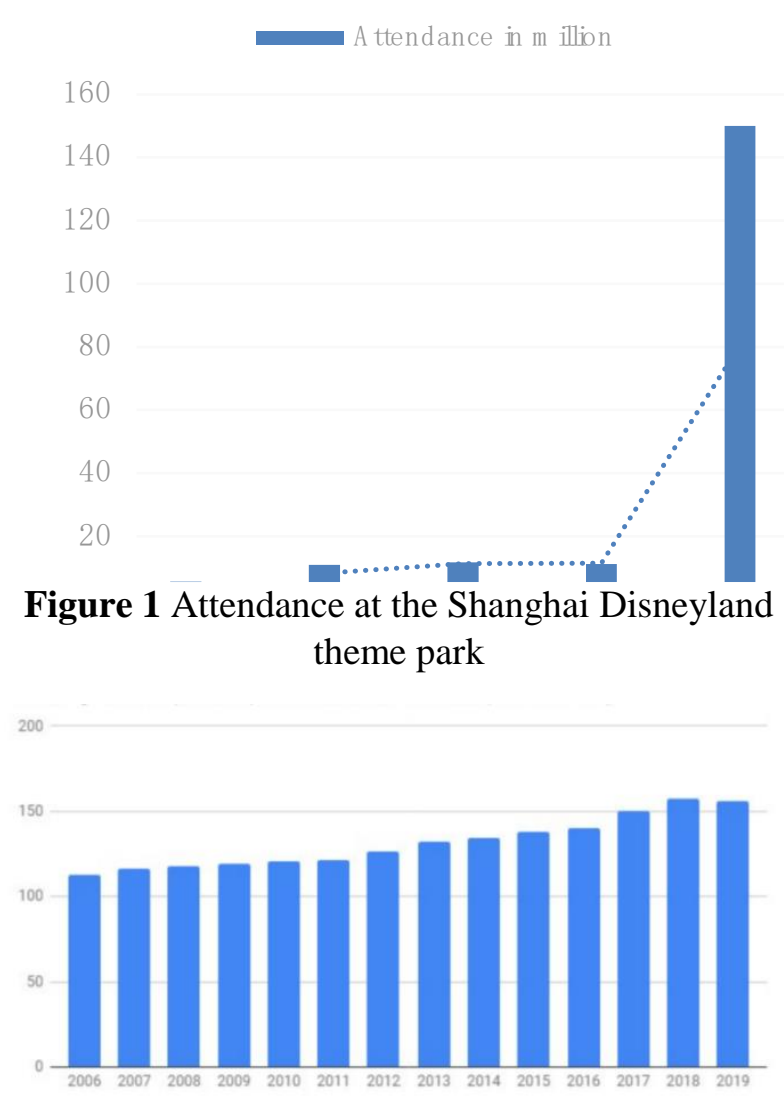

Figure2 Disney Parks (Global) Annual Attendance (in millions)

The comparison of Figure 1 and Figure 2 reveals that tourism awareness of Shanghai Disney theme park accounts for a large proportion, which is the embodiment of Disney localization.

\subsection{Specific site selection and reasons}

Table 5. Ranking of tourism revenue of major cities in china during the holiday in may 2021

\begin{tabular}{llll}
\hline Ranking & City & $\begin{array}{l}\text { Tourism income } \\
\text { (Hundred million) }\end{array}$ & $\begin{array}{l}\text { Reception } \\
\text { person } \\
(10000)\end{array}$ \\
\hline 1 & Shanghai & 400 & 1688.9 \\
2 & Chengdu & 170.2 & 1850.5 \\
3 & Chongqing & 124.7 & 1019.8 \\
4 & Xi'an & 106.6 & 1690 \\
5 & Beijing & 93 & 842.6 \\
6 & Guangzhou & 88.9 & 1084.8 \\
7 & Suzhou & 88 & 628 \\
8 & Hangzhou & 57.9 & 921 \\
9 & Zhengzhou & 57.6 & 1023 \\
10 & Nanjing & 50.5 & 527.8 \\
\hline
\end{tabular}

\section{CONCLUSION}

This paper first compares Disney with similar companies in different aspects. It summarizes that Disney's brand influence and publicity as an international brand are better than local enterprises, so
Disney should further expand in China. After that, Disney's driving effect on the surrounding environment is listed in different aspects. In terms of economy, the establishment of the Disney theme park can greatly promote the economic development of the surrounding areas. In terms of culture, the establishment of the Disney theme park can promote the integration of cultures in different regions, and tourists can experience the unique cultural works of other countries in Disney Park. In terms of education, Disney's animation works can help teenagers shape positive ideas. Finally, through the analysis of Disney's globalization and localization, Chengdu, as one of China's largest tourist cities, is speculated to be the most likely place to build a new Disney theme park in recent years.

\section{REFERENCES}

[1] Weng, J., Ding, Y., \& Yu, L. (2021). Measuring demand spillover of vacation town - a case of Shanghai Disney Resort. Asia Pacific Journal of Tourism Research, 26(2), 95-108.

[2] Boog, J., \& Milliot, J. (2020, February 24). Going Their Own Way: After deal, Disney, HBG discuss their strategies for the children's market. Publishers Weekly, 267(8), 5.

[3] Prevot, A., \& Hsieh, D.-M. (2012). The Marketing of Americana: Promoting the Walt Disney Company and Harley Davidson Motors in the French Market. Consortium Journal of Hospitality \& Tourism, 17(2), 40-51.

[4] Hongmei Yu. (2014). From Kundun to Mulan: A Political Economic Case Study of Disney and China. ASIANetwork Exchange, 22(1), 13-22.

[5] Yu, H. (2015). From Kundun to Mulan: A Political Economic Case Study of Disney and China. The ASIANetwork Exchange: A Journal for Asian Studies in the Liberal Arts, 22(1), 12-22.

[6] Bohas, A. (2015). Transnational Firms and the Knowledge Structure: The Case of the Walt Disney Company. Global Society, 29(1), 23-41.

[7] Carson, C. (2004). "Whole new worlds": Music and the disney theme park experience. Ethnomusicology Forum, 13(2), 228-235.

[8] Auster, C. J., \& Michaud, M. A. (2013). The Internet Marketing of Disney Theme Parks. SAGE Open, 3(1).

[9] Wu Dan.(2021).Theme Park Scenario-based Marketing Strategy research -- Taking Shanghai Disneyland as an example.[J]. Economic Research Journal,2021 (16):70-72. 
[10] Wei, W. (2018). Understanding values of souvenir purchase in the contemporary Chinese culture: A case of Shanghai Disney. Journal of Destination Marketing \& Management, 10, 36-48.

[11] Huang Yidi.(2017). Cross-cultural Management of Enterprises--Taking Disney as an Example.[J].Economics and management, 7.

[12] Weng, J., Ding, Y., \& Yu, L. (2018). Measuring demand spillover of vacation town -a case of Shanahai Disney Resort. Asia Pacific Journal of Tourism Research,1-14.

[13] Forman,J.(1992). Corporate Image and the Establishment of Disney. Mickey Mouse and the French Press. Technical Communication Quarterly, 1992(3), 224-250

[14] Hairong Zhao\&Ling Lu.((2018). Research on tourism motivation and the differences of the theme park tourists: a case study of Shanghai Disneyland and Fantawild in Wuhu.[J]. Hunan Geography,2018,33(04):153-160.

[15] Alden D L, Batra R. Brand positioning through advertising in Asia, North America, and Europe(1999): The role of global consumer clture[J]. Journal of Marketing,63(1)75-87.

[16] Anthony F\& Micky L(2009). Localizing a global amusement park: Hong Kong Disneyland[J]. Continuum:197-208.

[17] Winit W,Gregory G,Cleveland M,et al(2014). Global vs local brands: How home country bias and price differences impact brand evaluations[J]. International Marketing Review:102-128.

[18] Borrie W T.Disneyland and disney world(1999): Designing and prescribing the recreational experience[J].Loisir Et Société, 1999,22(1):71-82.

[19] Litvin S WGoldsmith R E,Pan B Electronic wordof-mouth in hospitality and tourism managementJ. Tourism Management,2008,29(3):458-468

[20] Leung D,Law R,Hoof HV.et al.Social media in tourism and hospitality A Iiterature reviewJ.Joumnal of Travel\&a mp: Tour-ism Marketing,2013,30(1-2):322

[21] Kang xinying\&Renhan, a comparative study of Chinese and foreign brand theme park hotel experience: based on the online review of Shanghai Disneyland hotel and guangzhou changelong hotel[J]. Journal of Taishan University,2020,42(05):41-49.

[22] Suzhou economic profile: A snapshot for foreign investors. China Briefing News. (2020, December
15). https://www.china-briefing.com/news/suzhouinvestment-stronghold-innovation-trailblazer-yrd/.

[23] Published by C. Textor, \& 15, M. (2021, March 15). China: Number of domestic tourists in Shanghai. Statista. https://www.statista.com/statistics/1133133/chinanumber-of-inbound-domestic-tourists-in-shanghai/.

[24] Weng, J., Ding, Y., \& Yu, L. (2021). Measuring demand spillover of vacation town - a case of Shanghai Disney Resort. Asia Pacific Journal of Tourism Research, 26(2), 95-108. https://doiorg.ezproxy.capilanou.ca/10.1080/10941665.2018. 1515090

[25] Hongmei Yu. (2014). From Kundun to Mulan: A Political Economic Case Study of Disney and China. ASIANetwork Exchange, 22(1), 13-22.

[26] W.Va. Gov. Wants A Population Boom And A Disney Theme Park. His Plan? Income Tax Cuts. (2021). All Things Considered.

[27] Boog, J., \& Milliot, J. (2020, February 24). Going Their Own Way: After deal, Disney, HBG discuss their strategies for the children's market. Publishers Weekly, 267(8), 5. 